\title{
Bryostroma popei - a new bryophilous ascomycete from the British Isles, with a worldwide key to the genus Bryostroma
}

\author{
George R. L. Greiff ${ }^{1} \&$ Paul F. Cannon ${ }^{2}$ (i)
}

Summary. The bryophilous Bryostroma popei is a novel ascomycete that infects the pleurocarpous moss Leptodictyum riparium. The morphology of the new species is described, illustrated and compared to other species in the genus. A key to the nine species of Bryostroma is provided.

Key Words. intracellular hyphae, muscicolous, parasitism.

\section{Introduction}

Bryophyte-associated fungi have been poorly understood in the British Isles despite a relatively high number of active bryologists in this region. This is in part due to a lack of crossover between bryology and mycology, as well as the difficulty of working with tiny, often cryptic, bryophilous fungi (Döbbeler 1997). The bryophilous habit has independently arisen multiple times in several fungal lineages, with convergent evolution resulting in systematic uncertainty in many morphological studies (see Stenroos et al. 2010).

An interesting ascomycete was detected during the investigation of collections from a bryophyte survey of low altitude, riparian ancient woodland on the Isle of Wight in southern England. Black, globose ascomata were inadvertently collected on a sample of the moss Leptodictyum riparium (Hedw.) Warnst., and subsequent analysis showed that these represented a hitherto undescribed ascomycete belonging to the genus Bryostroma Döbbeler. This sparsely-documented genus of moss-associated microfungi is currently represented by seven other European species (Döbbeler 1978, 1982) and one species from New Caledonia (Döbbeler \& Müller 2018). A ninth species of Bryostroma is described here.

\section{Material and Methods}

Initial measurements for this study were based on living material, using standard methods, a few hours after collection. Samples were first examined under a dissecting microscope before individual ascomata were extracted with fine forceps and a dissecting needle. Six ascomata were transferred to a slide and mounted in water. Measurements of the diagnostic features were made using a Leitz Laborlux 11 compound micro- scope. Further observations and measurements were made from preserved material by the second author, using an Olympus BH-2 compound microscope with Nomarski optics. Infected host plant stems were sectioned using a disposable razor blade and then stained in gently heated lactophenol cotton blue to visualise and measure the intracellular hyphae. These preparations were then compared to uninfected stems that were identically treated. The infected host shoots were then air-dried and preserved in the Kew Fungarium.

\section{New taxon}

Bryostroma popei Greiff $\mathcal{E}$ P.F.Cannon, sp. nov. (Dothideomycetes, incertae sedis). Type: UK, Isle of Wight, Havenstreet, Briddlesford Copse, on decaying stems of Leptodictyon riparium, UK grid reference SZ556900, 26 Sept. 2019, G. R. L. Greiff. Holotype (K(M) 255204). [Index Fungorum IF557422].

Fruitbodies 120 - 180 (-215) $\mu \mathrm{m}$ diam., 100 - 170 (-190) $\mu \mathrm{m}$ tall, subglobose, black, glabrous, solitary, superficial to slightly immersed in the host tissue. Ostiole $20-22 \mu \mathrm{m}$ in diameter, visible under the stereomicroscope, round, not protruding. Peridium $25-30 \mu \mathrm{m}$ thick, the surface layer consisting of thick-walled, angular dark brown cells, darker at the top than towards the base, outer cells $6.7-$ $12 \mu \mathrm{m}$ diam., mostly isodiametric, discontinuous giving the fruitbody a cracked appearance in transmitted light under high power magnification. Interascal filaments 2 $2.5 \mu \mathrm{m}$ diam., septate, fairly thick-walled, anastomosing, mostly fragmented or deliquescing at maturity, probably attached at both ends to the interior of the fruitbody. Asci variable in length depending on the number of spores, $53-75(-118) \times 11.8-14.0 \mu \mathrm{m}$, cylindric-clavate,

Accepted for publication 8 April 2020. Published online 17 December 2020

1 St Hilda's College, University of Oxford, Oxford, OX4 1DY, UK.

2 Royal Botanic Gardens, Kew, Richmond, Surrey, TW9 3AE, UK. e-mail: p.cannon@kew.org 
often with a short, narrowed foot, the apex rounded, thick-walled and fissitunicate with the internal layer staining orange in Lugol's solution, with a short broad ocular chamber, not bluing in iodine, 2-, 4-, 6- or 8spored with abortive spores occasionally present. Ascospores arranged obliquely uniseriately or biseriately, (20.3 -) 21.1 - $23.6(-25.5) \times(5.9-) 6.2-6.8(-7.3) \mu \mathrm{m}$, ellipsoidal, fusiform-ellipsoidal or narrowly clavate, distinctly constricted at the \pm median septum and with rare secondary septum development, hyaline, the upper cell slightly broader and more cylindrical than the lower cell, the apex obtuse and the base acute to obtuse, straight to slightly bent, single central guttules present in developing spores but later dividing into many (12+) small ones in mature spores, the wall minutely rugulose, mucilaginous sheath absent. Vegetative hyphae variable, to $7 \mu \mathrm{m}$ diam., hyaline to pale brown, intracellular in the stem of the host, polymorphic, thin-walled, branched, forming a small stromatic wedge beneath the fruitbodies that penetrates a short way into the host tissues. Appressoria absent. Anamorph unknown (Fig. 1).

RECOGNITION. Bryostroma popei resembles other members of the genus with 1-septate ascospores, namely B. acrocarpum Döbbeler \& Frank Müll., B. axillare (Racov.) Döbbeler, B. guttulatum Döbbeler \& Poelt, B. halosporum Döbbeler \& Poelt and B. racomitrii Döbbeler. It may be separated from these species by the properties of the asci, ascospores and host preference, as indicated in the key to species. Diagnostic features are especially the rather small ascomata, the asci that frequently contain fewer than eight ascospores, the ornamented ascospores without mucilaginous sheaths and the association with Leptodictyum riparium. See the key for further details. DISTRIBUTION. Europe: England, Isle of Wight. Only known from the type collection.

SPECIMENS EXAMINED. UK. Isle of Wight, Havenstreet, Briddlesford Copse, on decaying stems of Leptodictyum riparium, UK grid reference SZ555900, 26 Sept. 2019, G. R. L. Greiff. Holotype (K(M) 255204).

HABITAT. Riparian ancient woodland; alt. approx. 15 m. The host plant Leptodictyum riparium (Hedw.) Warnst. (Amblystegiaceae, Hypnales, Bryidae, Bryophyta) was growing in a seasonal stream.

CONSERVATION STATUS. Not formally assessed due to a lack of sustained collection effort and of the skills needed to detect it. The inconspicuous nature of the species also means that it is likely to be overlooked. It would presumably be considered for the present as Data Deficient.

ETYMOLOGY. popei, in honour of the Isle of Wight botanist, mycologist and excellent all-round naturalist Dr Colin R. Pope.
NOTES. Bryostroma species are often associated with the stem and lower parts of the leaves of their host plants (Döbbeler 2002). Most previously described members of the genus specifically colonise apical regions of their hosts (Döbbeler 1978, 1982; Döbbeler \& Müller 2018) with the majority of hosts being acrocarpous mosses. Only two other species of Bryostroma have previously been reported to grow on pleurocarpous mosses (Hypnales): B. necans on Pterigynandrum filiforme Hedw. and Thuidium assimile (Mitt.) A. Jaeger (syn. T. philibertii Limpr.), and B. halosporum on Pseudoleskeela catenulata (Brid. ex Schrad.) Kindb. Leptodictyum riparium is a creeping pleurocarpous moss (Smith 2004) and represents a new host for Bryostroma. B. popei exhibits similar behaviour to B. halosporum in that the new species also colonises the defoliated stems of its pleurocarpous host (Döbbeler 1978). The growing tips of the plants infected with $B$. popei were clear of fruitbodies and remained green, while damage and fruitbody formation occurred in older areas. This is a typical strategy of several other bryophilous ascomycetes that grow on creeping pleurocarpous mosses, particularly other Dothideomycetes such as species of Bryomyces Döbbeler 1978 (nom. illegit., non Bryomyces Miq. 1839) and Bryorella Döbbeler that grow on Thuidium spp. and Hylocomium splendens (Hedw.) Schimp. (Döbbeler 1978, 1979).

Bryostroma popei appears to be closely related to the other members of the genus with 1-septate spores. Bryostroma guttulatum is similar to B. popei, particularly in the dimensions of the ascomata and the general shape of the ascospores. They differ in that B. guttulatum is reported to have octosporous asci with spores slightly wider relative to their length and the guttules not appearing to divide when spores mature (Döbbeler 1978). The phylogenetic positions and ecological niches of the hosts of both parasites are also distinct. B. guttulatum colonises the subalpine Blindia acuta (Seligeriaceae, Grimmiales; Döbbeler, pers. comm. 2019) while Leptodictyum riparium, the host of $B$. popei, is a species common to damp ground or debris in lowland woodland. Bryostroma popei differs from $B$. halosporum in having significantly smaller ascomata; ascospores lacking mucilaginous sheaths and epispore ornamentation, as well as a different host preference (see Döbbeler 1978).

Bryostroma popei is also similar to the type of the genus, $B$. racomitrii, in that it appears to have reduced fertility as a result of asci developing with fewer than eight ascospores. Döbbeler (1978) reported $B$. racomitrii to have four- and eight-spored asci. B. popei has asci containing two, four, six or eight spores that progress to maturity, and all fruitbodies examined during this study contained asci with varying numbers of spores. Degeneration of two 

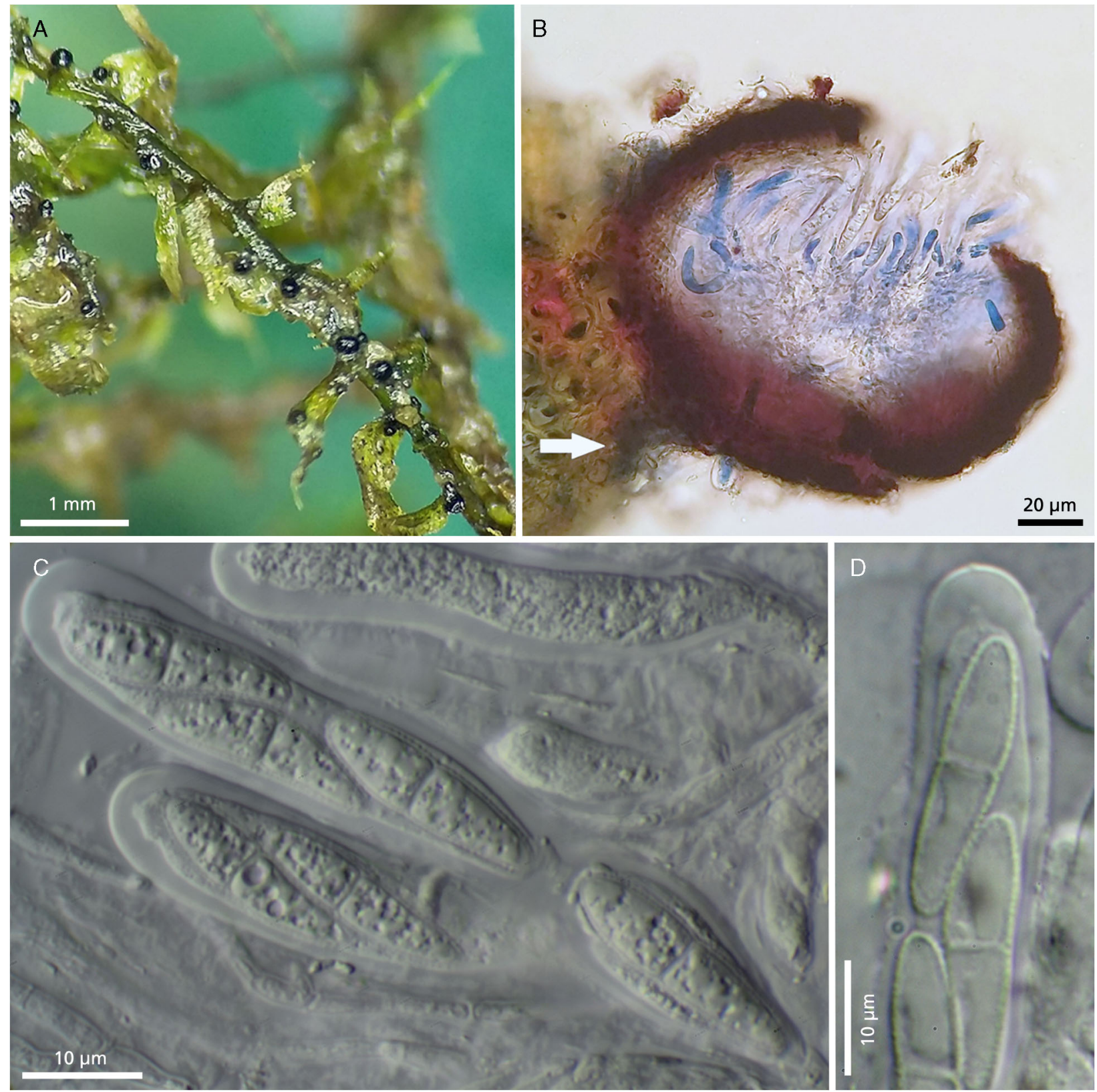

Fig. 1. Bryostroma popei. A ascomata on decaying stem of Leptodictyum riparium; B section through ascoma, showing the oblique basal stromatic peg (arrow); C asci, ascospores and degenerating interascal tissue, mounted in water; D ascus and ascospores mounted in warmed lactic acid, showing the spore ornamentation.

ascospores was observed several times in four-spored asci, resulting in only two ascospores developing normally. At this stage, the cause of this phenomenon is unclear and more samples are required to see if it is a genuine developmental feature of B. popei. With only a small number of European records for each species in the genus Bryostroma (Döbbeler \& Müller 2018), and with only B. trichostomi previously being recorded in Britain and Ireland (Spooner
2001; Greiff, unpub.), many aspects of the development and ecology of the species in this genus remain unclear.

Leptodictyum riparium is a wetland moss with an almost cosmopolitan lowland distribution (Smith 2004). It is the most common member of the Amblystegiaceae in and around rather eutrophic habitats such as wooded swamps and water courses in much of southern England and on the Isle of 
Wight (Pope et al. 2003). Infected plants were collected inadvertently during a bryophyte survey of the type locality, Briddlesford Copse, on the Isle of Wight. Leptodictyum riparium was forming mats on a silt-covered fallen tree trunk in the flood zone of a stream near a boundary of the wood. Associated bryophytes in similar niches were Leskea polycarpa Ehrh. ex Hedw. and Bryoerythrophyllum recurvirostrum (Hedw.) P.C.Chen. Homalia trichomanoides (Hedw.) Schimp., Neckera complanata (Hedw.) Huebener and Anomodon viticulosus (Hedw.) Hook. \& Taylor were also present on trees around the stream. The infected plants were collected to confirm their identity because they were partly encrusted with sediment, greyish in colour and not looking sufficiently typical for confident field identification.
Several plants from rotting wood in a damp section of Salix swamp at a different site were subsequently collected in vain for the presence of $B$. popei. It may be that the fungus is confined to hosts in strictly riparian microhabitats or that $L$. riparium is not the primary host of the fungus. Further collections are required to get a better idea of the ecology and host preferences of this new species. Leptodictyum riparium is also reported to be parasitised by Pleospora herbarum (Pers.) Rabenh. (syn. Stemphylium botryosum Wallr.) (Davey \& Currah 2006; Prior 1966). Aside from this ubiquitous and plurivorous necrotrophic pathogen, of which there are several related bryophilous teleomorphs, no other bryophilous Dothideomycetes have been recorded from this host (Ellis \& Ellis 1988; Felix 1988; Racovitza 1959).

\section{Key to the genus Bryostroma}

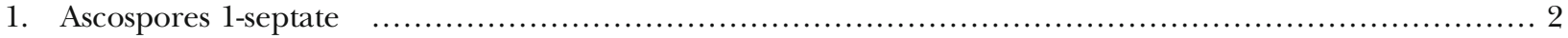

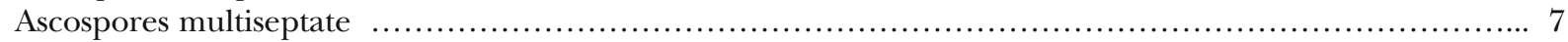

2. Mature ascospores constricted at the septum, and covered by a hyaline mucilaginous sheath ................ 3

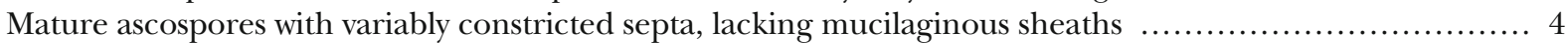

3. Ascomata to $450 \mu \mathrm{m}$ diam.; ascospores (18 -) $21-26(-28) \times 7-9 \mu \mathrm{m}$, with a broad mucilaginous sheath to $2.5 \mu \mathrm{m}$ thick; on Pseudoleskella catenulata ........................................................... B. halosporum Ascomata to $220 \mu \mathrm{m}$ diam.; ascospores $2226(-28) \times 6-8(-9) \mu \mathrm{m}$, with a narrow mucilaginous sheath $\mathrm{c}$. $1 \mu \mathrm{m}$ thick; on Blindia acuta ............................................................. guttulatum

4. Ascospores weakly or not constricted at the septum, smooth-walled; ascomata developing at shoot apices or in

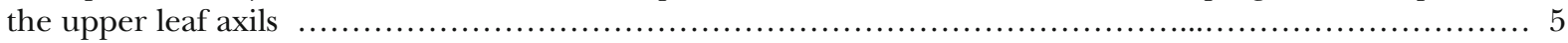
Ascospores distinctly constricted at the septum, minutely rugulose, (20.3-) $21.1-23.6(-25.5) \times(5.9-) 6.2-6.8(-$ 7.3) $\mu \mathrm{m}$; asci frequently with fewer than 8 spores; ascomata 120 - $180(-215) \mu \mathrm{m}$ diam., developing on non-apical parts of host plants: on leafless stems or decomposing leaves, on Leptodictyum riparium ....................... B. popei

5. Ascospores not constricted at the septum, $(30-) 33-40(-46) \times(6-) 7-8(-9) \mu \mathrm{m}$; asci 4- or 8-spored; ascomata 470 - $720 \mu \mathrm{m}$ diam.; on Racomitrium lanuginosum ..................................... B. racomitrii Ascospores not or slightly constricted at the septum, $\leq 30 \mu \mathrm{m}$ in length; asci 8-spored; ascomata to $410 \mu \mathrm{m}$

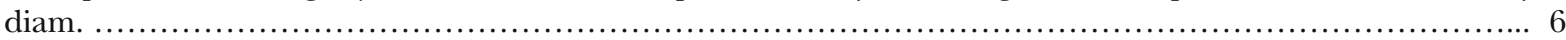

6. Ascospores (13-) $14.5-17(-19) \times(4-) 4.5-5.5 \mu \mathrm{m}$; ascomata $210-300$ (- 410) $\mu \mathrm{m}$ diam.; on Archidium

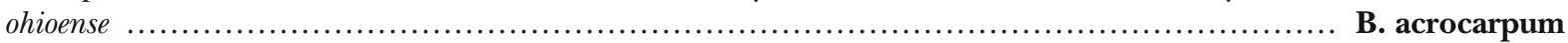
Ascospores (20 -) 23 - $30 \times 6.0$ - $7.5 \mu \mathrm{m}$; ascomata 250 - $350 \mu \mathrm{m}$ diam. on Didymodon acutus agg. and Ditrichum flexicaule

B. axillare

7. Mature ascospores 3-septate, (34-) $40-55(-62) \times(6-) 7-9(-10) \mu \mathrm{m}$, ascomata to $310 \mu \mathrm{m}$ diam.; mycelium intercellular, biotrophic on several Pottiaceae (recently recorded in Britain by G.G. on Trichostomum crispulum, T. brachydontium and Didymodon fallax) B. trichostomi Mature ascospores at least often more than 3-septate; mycelium intracellular .......................... 8

8. Mature ascospores 3-, 5- (-6)-septate with mucilaginous sheaths, $34-45(-63) \times 9-11.5(-14) \mu \mathrm{m}$, ascomata $140-$ $230 \mu \mathrm{m}$ diam.; necrotrophic, on Grimmia sp., Pterygynandrum filiforme and Thuidium assimile .... B. necans Mature ascospores 5- to 8-septate, (33 -) 42 - 57 (-65) $\mu \mathrm{m}$; ascomata 330 - $550 \mu \mathrm{m}$ diam.; on Bryum argenteum

\section{Acknowledgements}

GG would like to offer gratitude to Dr Peter Döbbeler and Dr Colin Pope. Many thanks to The People's Trust for Endangered Species for site permissions.
Open Access This article is licensed under a Creative Commons Attribution 4.0 International License, which permits use, sharing, adaptation, distribution and reproduction in any medium or format, as long as 
you give appropriate credit to the original author(s) and the source, provide a link to the Creative Commons licence, and indicate if changes were made. The images or other third party material in this article are included in the article's Creative Commons licence, unless indicated otherwise in a credit line to the material. If material is not included in the article's Creative Commons licence and your intended use is not permitted by statutory regulation or exceeds the permitted use, you will need to obtain permission directly from the copyright holder. To view a copy of this licence, visit http://creativecommons.org/ licenses/by/4.0/

\section{References}

Davey, M. L. \& Currah, R. S. (2006). Interactions between mosses (Bryophyta) and fungi. Canad. J. Bot. 84: 1509 - 1519.

Döbbeler, P. (1978). Moosbewohnende Ascomyceten I. Die pyrenocarpen, den Gametophyten besiedelnden Arten. Mitt. Bot. Staatssamml. München 14: 1 - 360.

(1979). Moosbewohnende Ascomyceten III. Einige neue Arten der Gattungen Nectria, Epibryon und Punctillum. Mitt. Bot. Staatssamml. München 15: 193 - 221.

(1982). Moosbewohnende Ascomyceten VI. Einige neue Pyrenomyceten. Mitt. Bot. Staatssamml. München 18: 341 - 358.

(1997). Biodiversity of bryophilous ascomycetes. Biodivers. Conserv. 6: 721 - 738.
(2002). Microniches occupied by bryophilous ascomycetes. Nova Hedwigia 75: 275 - 306.

\& Müller, F. (2018). Bryostroma acrocarpum - a novel muscicolous ascomycete from New Caledonia. Herzogia 31: 109 - 113.

Ellis, M. B. \& Ellis, J. P. (1988). Microfungi on Miscellaneous Substrates: An Identification Handbook. New Enlarged Edition. Richmond Publishing, Slough.

Felix, H. (1988). Fungi on bryophytes, a review. Bot. Helvet. 98: 239 - 269.

Pope, C. R., Snow, L. \& Allen, D. (2003). The Isle of Wight Flora. Dovecote Press, Dorset.

Prior, P. V. (1966). A new fungal parasite of mosses. Bryologist 69: 243 - 246.

Racovitza, A. (1959). Étude systématique et biologique des champignons bryophiles. Mém. Mus. Natl. Hist. Nat., Sér. B, Bot. 10 (fasc. 1): 1 - 288, pl. 1 - 84 .

Smith, A. J. E. (2004). The Moss Flora of Britain and Ireland. Second Edition. Cambridge University Press, Cambridge.

Spooner, B. M. (2001). New British records. Mycologist 15: $74-76$.

Stenroos, S., Laukka, T., Huhtinen, S., Döbbeler, P., Myllys, L., Syrjänen, K. \& Hyvönen, J. (2010). Multiple origins of symbioses between ascomycetes and bryophytes suggested by a five-gene phylogeny. Cladistics 26 (3): 281 - 300.

\section{Publisher's Note}

Springer Nature remains neutral with regard to jurisdictional claims in published maps and institutional affiliations. 